Yanglong Li*, Shusen Cheng and Zhifeng Wang

\title{
Corrosion Behavior of Ceramic Cup of Blast Furnace Hearth by Liquid Iron and Slag
}

DOI 10.1515/htmp-2015-0040

Received February 12, 2015; accepted October 10, 2015

\begin{abstract}
Three kinds of sample bricks of ceramic cups for blast furnace hearth were studied by dynamic corrosion tests based on different corrosion systems, i.e., liquid iron system, liquid slag system and liquid ironslag system. Considering the influence of temperature and sample rotational speed, the corrosion profiles and mass loss of the samples were analyzed. In addition, the microstructure of the corroded samples was observed by optical microscope (OM) and scanning electron microscope (SEM). It was found that the corrosion profiles could be divided into iron corrosion region, slag corrosion region and iron-slag corrosion region via corrosion degree after iron-slag corrosion experiment. The most serious corrosion occurred in iron-slag corrosion region. This is due to Marangoni effect, which promotes a slag film formed between liquid iron and ceramic cup and results in local corrosion. The corrosion of the samples deepened with increasing temperature of liquid iron and slag from $1,623 \mathrm{~K}$ to $1,823 \mathrm{~K}$. The variation of slag composition had greater influence on the erosion degree than that of rotational speed in this experiment. Taking these results into account the ceramic cup composition should be close to slag composition to decrease the chemical reaction. A microporous and strong material should be applied for ceramic cup.
\end{abstract}

Keywords: blast furnace, hearth, ceramic cup, liquid iron, liquid slag, corrosion

\section{Introduction}

The life of blast furnace is mainly determined by the life of hearth lining presently $[1,2]$. There is a hostile working environment in blast furnace hearth, such as high temperature, physical wear, chemical corrosion caused by

*Corresponding author: Yanglong Li, School of Metallurgical and Ecological Engineering, University of Science and Technology Beijing, Beijing 100083, China, E-mail: yanglong.xlnm@163.com Shusen Cheng, School of Metallurgical and Ecological Engineering, University of Science and Technology Beijing, Beijing 100083, China Zhifeng Wang, Beijing Tonda Refractory technology Co., Ltd., Beijing 100085, China molten iron and slag. Due to good performance of penetration resistance, hot metal resistance and preventing heat loss [3-5], the ceramic cup has been widely used as an important part of hearth lining. However, the rapid erosion of hearth and even breakout events still occurs sometimes. It is undisputed that hearth lining especially ceramic cup is eroded rapidly $[6,7]$. Particularly, the lining near taphole is always a serious corrosion region, which is caused by not only liquid flow with high velocity, but also the mutual effect of liquid iron and slag. Hence, the corrosion behavior of ceramic cup by liquid iron and slag has attracted much attention, and the phenomena and mechanism are worth further research.

The numerical simulation [8-15] and dissection investigation $[16,17]$ of hearth bottom have been taken by some researchers. Meanwhile, the corrosion behavior of aluminum or magnesium refractory materials by slag has been investigated [18-22]. But these tests were generally carried out by static crucible method. In fact, hot metal flow becomes more turbulent in blast furnace hearth due to high production and poor deadman permeability [18]. The remarkable change of liquid level, especially the change of iron-slag interface, also occurs during tap cycle with a floating deadman [9, 23]. However, studies on dynamic corrosion of ceramic cup by liquid iron and slag are rare and insufficient. The erosion phenomena of ceramic cup with different corrosion systems, i.e., liquid iron system, liquid slag system and liquid iron-slag system, are still necessary to investigate. Therefore, the dynamic corrosion tests of three kinds of ceramic cups were conducted by different corrosion systems. The influence of temperature and the change of slag composition were also discussed. It is imperative to understand the corrosion mechanisms of ceramic cup to prolong the blast furnace campaign.

\section{Experimental}

\section{Materials}

Three kinds of sample bricks of ceramic cups were used to investigate the corrosion by liquid iron and slag. These bricks are ordered as No. 1, No. 2 and No. 3 and the 
Table 1: Chemical and physical properties of ceramic cups.

\begin{tabular}{|c|c|c|c|c|}
\hline \multirow[t]{2}{*}{ Property } & & \multicolumn{3}{|c|}{ Sample No. } \\
\hline & & 1 & 2 & \\
\hline \multirow[t]{4}{*}{ Chemical compositions (\%) } & $\mathrm{Al}_{2} \mathrm{O}_{3}$ & 55.45 & 69.39 & 60.31 \\
\hline & $\mathrm{SiO}_{2}$ & & 16.49 & 14.76 \\
\hline & $\mathrm{SiC}$ & 36.44 & 5.23 & 12.25 \\
\hline & $\mathrm{Fe}_{2} \mathrm{O}_{3}$ & 0.45 & 1.23 & 1.09 \\
\hline Bulk density $\left(\mathrm{g} \mathrm{cm}^{-3}\right)$ & & 2.99 & 2.77 & 2.73 \\
\hline Apparent porosity (\%) & & 15.0 & 15.6 & 13.5 \\
\hline Cold crushing strength ( $\mathrm{MPa})$ & & 78.6 & 76.7 & 55.7 \\
\hline
\end{tabular}

chemical and physical properties are listed in Table 1 . The size of each sample brick is $40 \mathrm{~mm} \times 40 \mathrm{~mm} \times 300$ $\mathrm{mm}$, as shown in Figure 1(a). A hole with a diameter of 15 $\mathrm{mm}$ is drilled at one side of the sample to fix the sample conveniently. The appearance picture of initial sample is presented in Figure 1(b).

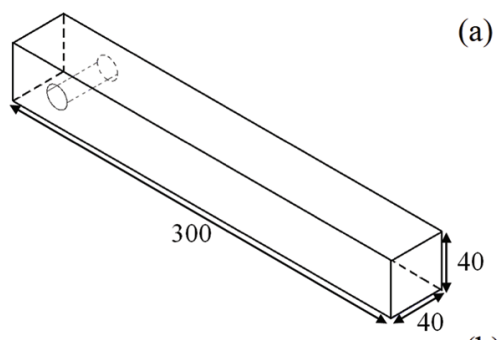

(a)

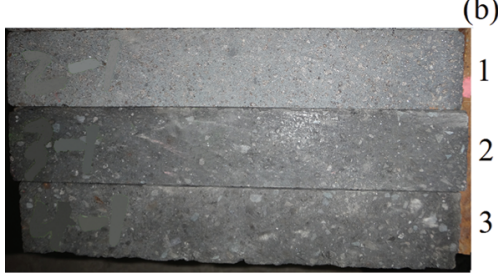

Figure 1: Schematic of the sample and appearance picture of the initial samples.

\section{Experimental equipment and methods}

Figure 2 shows the schematic diagram of the experimental equipment. The samples were fixed at the sample slots. In order to simulate the flow state of liquid iron and slag, these samples can rotate with the slots at a selectable speed during the experiment. A weighted amount of solid iron and slag was put into the graphite crucible. And then the crucible was heated to melt the iron and slag. The temperature of liquid iron and slag was monitored and maintained by a thermocouple located on the outside surface of graphite crucible. At the beginning of heating process, the samples were preheated above the crucible. The duration of heating

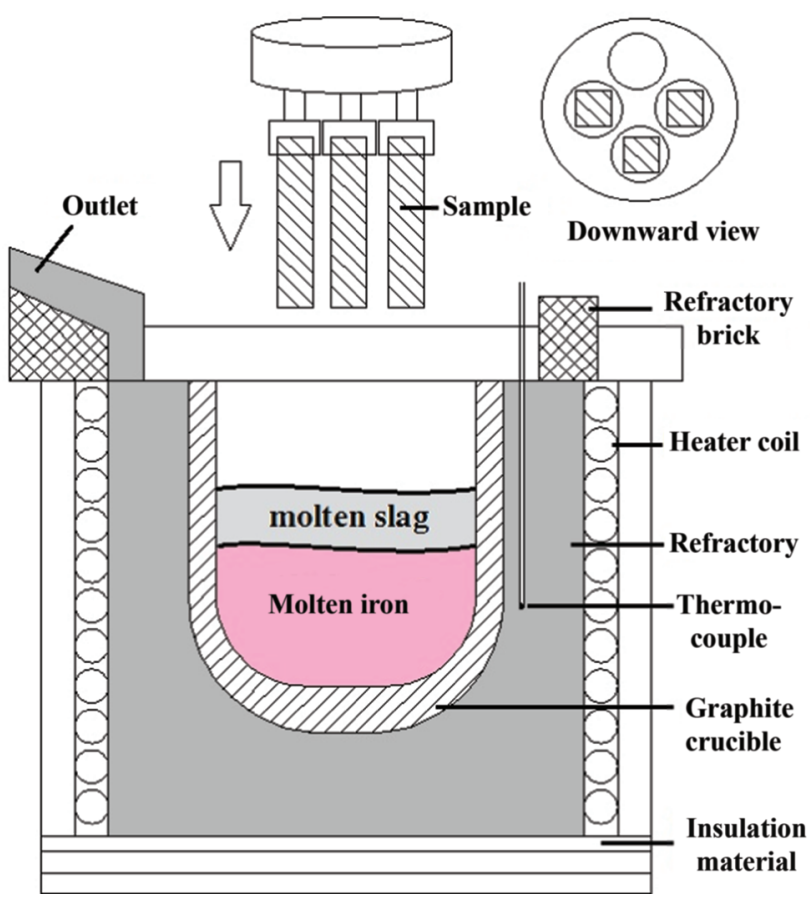

Figure 2: Schematic diagram of the experimental equipment.

process was more than $1 \mathrm{~h}$ from room temperature to test temperature. The samples were preheated sufficiently to minimize the influence of thermal shock. When the liquid reached the test temperature, the samples were immersed into the liquid about $80 \mathrm{~mm}$ depth for $30 \mathrm{~min}$. The samples were then cooled.

To observe the samples conveniently and to take out the samples on time, the experiments were carried out in the open environment. Although it is reducing atmosphere within a blast furnace, the influence of atmosphere on immersed part of the sample is little in these experiments.

\section{Experimental conditions}

Seven groups of experiments were conducted in total. Table 2 lists the experimental conditions. Group 1-3 experiments were carried out at different temperatures and the corrosion system was only liquid iron $(24.45 \mathrm{~kg})$.

The quaternary slag was utilized to simulate the blast furnace slag. Table 3 shows the composition of quaternary slag system. For group 4 and 5 experiments, the corrosion system was liquid slag and test temperature was $1,773 \mathrm{~K}$ and $1,823 \mathrm{~K}$, respectively. However, because of utilization of induction coil for heating, enough iron must be added to melt the slag. Therefore, $9.3 \mathrm{~kg}$ of iron was used to melt $4.07 \mathrm{~kg}$ of slag. The thickness of liquid 
Table 2: Seven groups of corrosion experiments.

\begin{tabular}{|c|c|c|c|c|c|c|}
\hline Exp. No. & $\begin{array}{l}\text { Corrosion } \\
\text { system }\end{array}$ & Temperature (K) & $\begin{array}{l}\text { Sample rotational } \\
\text { speed (rev } \mathrm{min}^{-1} \text { ) }\end{array}$ & Iron mass (kg) & Slag mass (kg) & $\begin{array}{r}\text { Mass ratio of iron } \\
\text { and slag }\end{array}$ \\
\hline 1 & Iron & 1623 & 25 & 24.45 & 0 & 0 \\
\hline 2 & Iron & 1723 & 25 & & & \\
\hline 3 & Iron & 1823 & 25 & & & \\
\hline 4 & Slag & 1773 & 25 & 9.30 & 4.07 & 0.438 \\
\hline 5 & Slag & 1823 & 25 & & & \\
\hline 6 & Iron-slag & 1773 & 25 & 17.53 & 2.00 & 0.114 \\
\hline 7 & Iron-slag & 1773 & 50 & & & \\
\hline
\end{tabular}

Table 3: Composition of quaternary slag system.

\begin{tabular}{lrrrr}
\hline Composition & $\begin{array}{r}\text { Content } \\
\text { (\%) }\end{array}$ & $\begin{array}{r}\text { Binary } \\
\text { basicity }\end{array}$ & $\begin{array}{r}\text { Ternary } \\
\text { basicity }\end{array}$ & $\begin{array}{r}\text { Quaternary } \\
\text { basicity }\end{array}$ \\
\hline $\mathrm{CaO}$ & 43 & 1.23 & 1.46 & 1.04 \\
$\mathrm{MgO}$ & 8 & & & \\
$\mathrm{SiO}_{2}$ & 35 & & & \\
$\mathrm{Al}_{2} \mathrm{O}_{3}$ & 14 & & & \\
\hline
\end{tabular}

slag in the crucible was more than $80 \mathrm{~mm}$ so that the samples were only corroded by liquid slag.

The corrosion system of group 6 and 7 experiments was liquid iron and slag; $2 \mathrm{~kg}$ of slag and $17.53 \mathrm{~kg}$ of iron were used. The thickness of liquid slag was about $40 \mathrm{~mm}$ in the crucible. The sample rotational speed was $25 \mathrm{rev} / \mathrm{min}$ in each experiment except No. 7 experiment (50 rev/min).

\section{Results and discussion \\ Influence of corrosion system}

Figure 3(a) shows the macro-appearances of No. 1-3 samples after liquid iron corrosion at 1,823 $\mathrm{K}$. The corrosion surface of the samples can be divided into two regions including unreacted region and iron corrosion region. There is almost no significant change in both regions. But the surface in iron corrosion region is a little coarser than that in the unreacted region. And also there

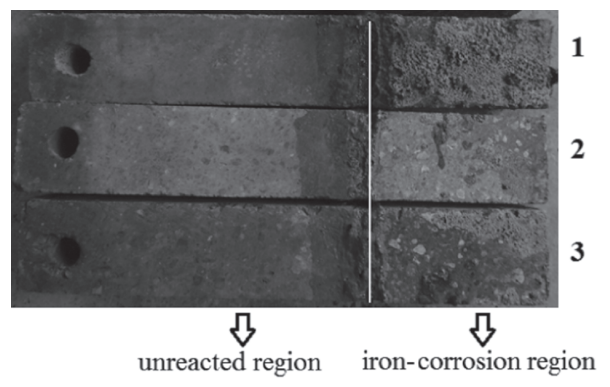

(a)

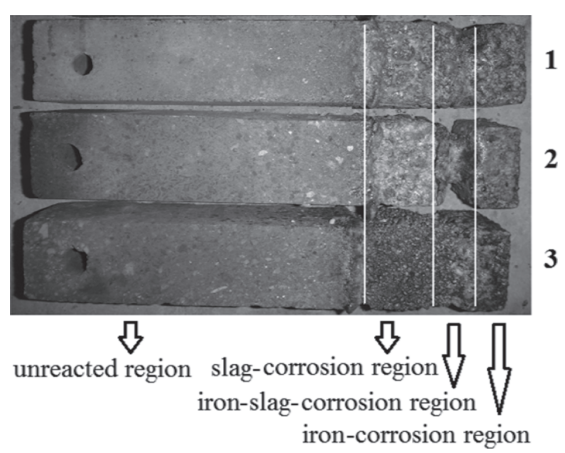

(c)

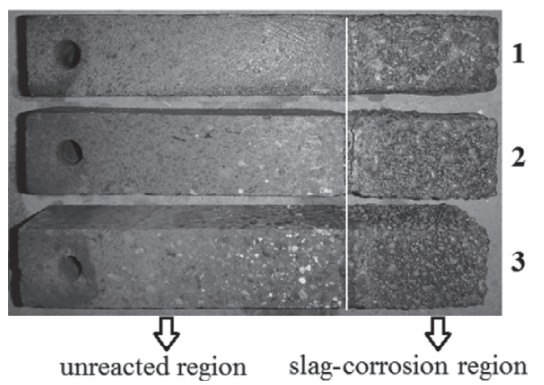

(b)
Figure 3: Appearances of No. 1-3 samples after different experiments. (a) Iron corrosion experiment at 1,823 K. (b) Slag corrosion experiment at $1,823 \mathrm{~K}$. (c) Ironslag corrosion experiment at $1,773 \mathrm{~K}$. 
is hardly any iron adhering on the surfaces. It indicates that ceramic cup has poor wettability with molten iron and good resistance to iron corrosion.

Figure 3(b) presents the macro-appearances of the samples after liquid slag corrosion at 1,823 $\mathrm{K}$. The surface of the samples can be divided into unreacted region and slag corrosion region according to the corrosion degree. It can be observed that there is almost no change in the unreacted region. However, in the slag corrosion region, all the surfaces of No. 1-3 samples become coarser than those of initial samples. A small amount of slag adheres on the surfaces and the aggregates are protuberant. In addition, there are some cracks near the border between these two regions of No. 2 sample. The slag corrosion of No. 1-3 ceramic cups is obvious.

Figure 3(c) presents the appearances of No. 1-3 samples after iron-slag corrosion at 1,773 $\mathrm{K}$. The features of iron-slag corrosion are different from those of slag corrosion or iron corrosion. Four distinguishing regions can be observed clearly, which are unreacted region, slag corrosion region, iron-slag corrosion region and iron corrosion region. The most serious corrosion takes place in the slag-iron corrosion region, which is near the interface between liquid iron and slag. The features of slag corrosion region are similar with the results in the case of slag corrosion experiment and the features of iron corrosion region are also same as the results in the case of iron corrosion experiment. In particular, the corrosion of No. 2 sample is the most serious and the cracks can be seen clearly.

The mass loss percentage of the sample after the corrosion, $r_{\mathrm{m}}$, can be calculated by eq. (1).

$$
r_{\mathrm{m}}=\frac{m_{1}-m_{2}}{m_{1}}
$$

where $m_{1}$ and $m_{2}$ are the sample mass before and after experiment, respectively.

Figure 4 shows the mass loss percentage of No. 1-3 samples for different corrosion experiments at 1,823 K. When ceramic cup is eroded by liquid iron or slag separately, the mass loss of the sample is little. However, if iron and slag corrode the ceramic cup simultaneously, the samples have the maximum mass loss, which are $2.6 \%, 4.7 \%$ and 3.5\%, respectively. The mass loss percentage of No. 2 sample is the largest.

In order to analyze the difference of the corrosion regions with liquid iron-slag system, the length and mass loss of different corrosion regions are measured according to the corrosion profile of each sample. The length of each region is measured along the sample length for four times at different surfaces and takes an

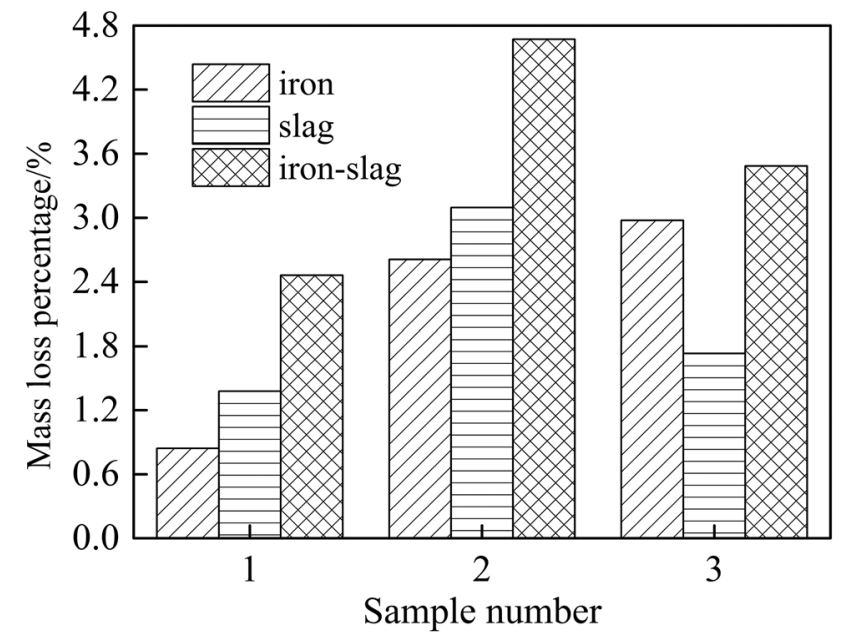

Figure 4: Influence of corrosion system on mass loss percentage.

average. Because the immersed depth of three samples into liquid is the same, the length of corrosion regions is basically the same for different samples. Figure 5 presents the length percentage and mass loss percentage of different regions after iron-slag corrosion experiment. It can be seen that mass loss of iron-slag corrosion region is the largest, whereas its length is the smallest for all samples. It's indicated that the most serious corrosion arises in the iron-slag corrosion region. The iron corrosion degree of ceramic cup is the lightest.

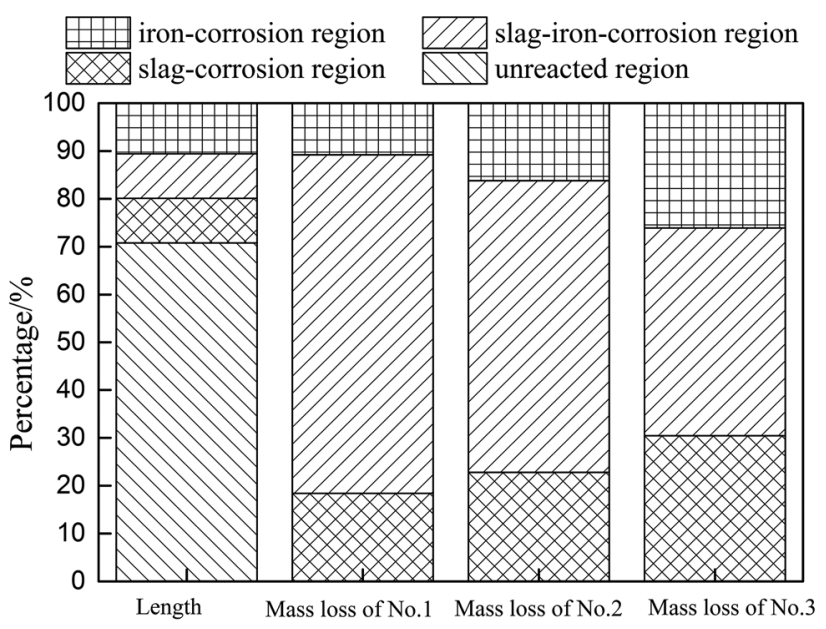

Figure 5: Length percentage and mass loss percentage of different regions after iron-slag corrosion experiment.

\section{Influence of temperature}

Figure 6(a) presents the influence of temperature on mass loss in iron corrosion experiment. An increase in 


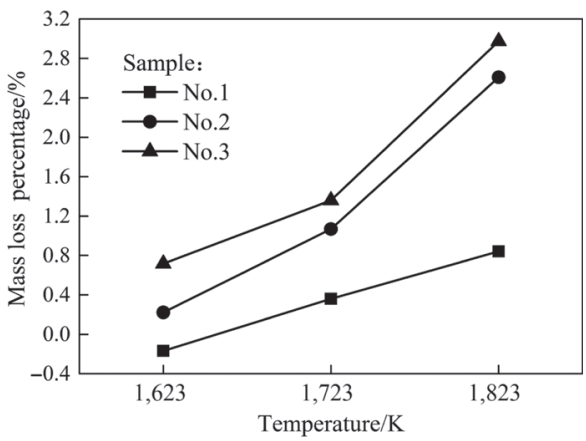

(a)

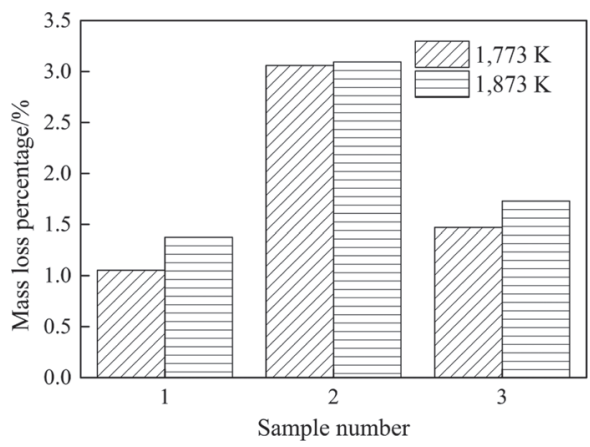

(b)
Figure 6: Influence of temperature on mass loss percentage. (a) Iron corrosion experiment. (b) Slag corrosion experiment. temperature from $1,623 \mathrm{~K}$ to $1,823 \mathrm{~K}$ causes a significant increase in mass loss. It is indicated that the ceramic cups are eroded more seriously by liquid iron with higher temperature.

The influence of temperature on mass loss in slag corrosion experiment is shown in Figure 6(b). In order to make the slag melt completely and flow smoothly, the test temperature for slag corrosion begins from 1,773 K. The results show modest progression of corrosion with increasing temperature from $1,773 \mathrm{~K}$ to $1,823 \mathrm{~K}$. A high slag temperature will intensify the corrosion.

It should be noted that the penetration of the liquid iron and slag will influence the mass of the sample, but it is difficult to estimate it quantitatively in these experiments. Therefore, there might be some inaccuracy in mass losses without considering the penetration of the liquids. In Figure 6(a), the negative mass loss of No. 1 sample at 1,623 $\mathrm{K}$ might be caused by this reason. But the variation of mass loss percentage of the samples with temperature is still correct.

\section{Influence of slag composition change}

At the last two group experiments (group 6 and 7), the different sample rotational speeds were investigated. Because it was difficult to renew the slag for each group experiment, the slag was not replaced during these two experiments. Therefore, the composition of slag system changed after the corrosion experiments. Table 4 shows the composition of quaternary slag system after the experiments. Compared with Table 3, the content of $\mathrm{SiO}_{2}$ and $\mathrm{Al}_{2} \mathrm{O}_{3}$ as well as the binary basicity increased.

Some research suggests that the refractory will be eroded more severely with increasing rotational speed $[24,25]$. However, in these experiments, the mass loss percentage of the samples at $50 \mathrm{rev} / \mathrm{min}$ is less than that
Table 4: Composition of quaternary slag system after the experiment.

\begin{tabular}{lrcrr}
\hline Composition & $\begin{array}{r}\text { Content } \\
\text { (\%) }\end{array}$ & $\begin{array}{r}\text { Binary } \\
\text { basicity }\end{array}$ & $\begin{array}{r}\text { Ternary } \\
\text { basicity }\end{array}$ & $\begin{array}{r}\text { Quaternary } \\
\text { basicity }\end{array}$ \\
\hline $\mathrm{CaO}$ & 40.36 & 1.29 & 1.52 & 0.94 \\
$\mathrm{MgO}$ & 7.14 & & & \\
$\mathrm{SiO}_{2}$ & 31.27 & & & \\
$\mathrm{Al}_{2} \mathrm{O}_{3}$ & 19.26 & & & \\
\hline
\end{tabular}

at $25 \mathrm{rev} / \mathrm{min}$, which is shown in Figure 7. This phenomenon is mainly caused by the change of slag composition due to dissolution and reaction of ceramic cup continually. The phase diagram of this slag at $1,773 \mathrm{~K}$ is calculated by FactSage software, as shown in Figure 8. In the figure, the slag composition is initially at point $\mathrm{A}$ in the experiment at $25 \mathrm{rev} / \mathrm{min}$, whereas it moves to point $\mathrm{B}$ in the experiment at $50 \mathrm{rev} / \mathrm{min}$. Because $\mathrm{Al}_{2} \mathrm{O}_{3}$ of ceramic

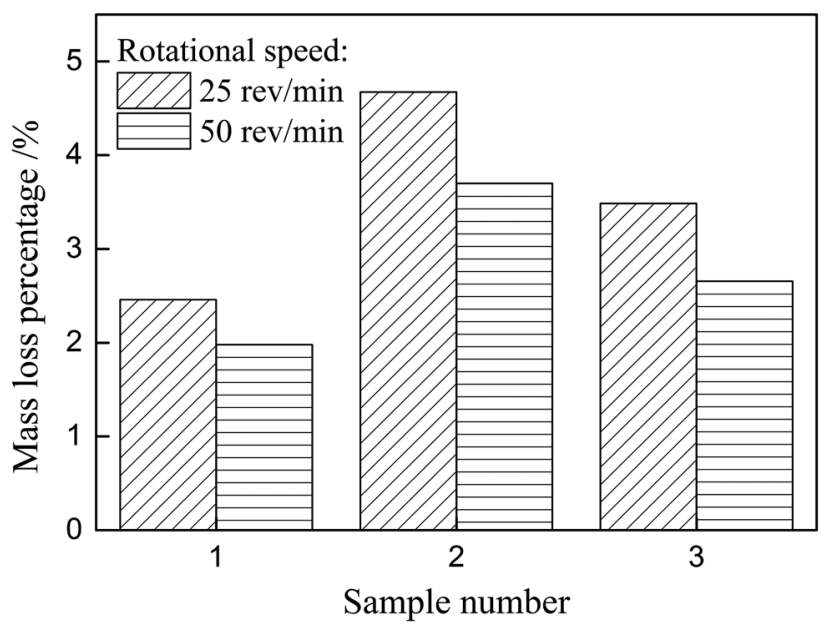

Figure 7: Influence of rotational speed on mass loss percentage at $1,773 \mathrm{~K}$. 


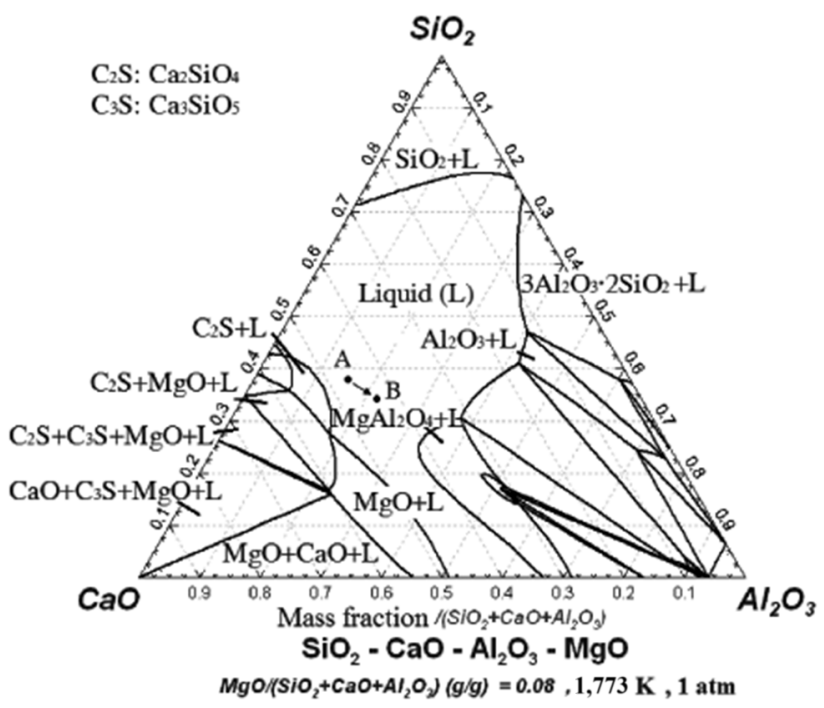

Figure 8: Phase diagram of slag at 1,773 K.

cup dissolves into the slag gradually, the content of $\mathrm{Al}_{2} \mathrm{O}_{3}$ increases and slag composition changes from point $\mathrm{A}$ to point $\mathrm{B}$. The activity of $\mathrm{Al}_{2} \mathrm{O}_{3}$ also increases from 0.0618 to 0.1256 (calculated by FactSage) and the concentration of $\mathrm{CaO}, \mathrm{MgO}$ and $\mathrm{SiO}_{2}$ reduces. Finally, the chemical corrosion rate and dissolution rate decrease.

\section{Optical microscope and scanning electron microscope study}

Figure 9 shows the OM (optical microscope) surface images of the samples before and after slag-iron corrosion experiment. It can be seen that the surfaces of original samples are flat. However, many holes are formed after the slag-iron corrosion. The surfaces also become rough. Especially in No. 2 and 3 samples, there are lots of large holes on the surface after corrosion experiments, which indicate that they have bad slag resistance.

Figure 10 presents the scanning electron microscope (SEM) profile images of No. 1 and 2 samples after slagiron corrosion experiment. Because there is almost no $\mathrm{CaO}$ in the original samples, the content of $\mathrm{Ca}$ can reflect the penetration depth of liquid slag. In the figure, there is no obvious separated layer. It can be seen that the slag penetration of No. 2 sample is much deeper than that of No. 1 sample. That is to say, the molten slag is easier to penetrate into No. 2 sample. Therefore, the slag resistance of No. 1 sample is obviously better than that of No. 2 sample.

\section{Corrosion mechanism of ceramic cup by liquid iron and slag}

In the present experiments, the most serious corrosion appeared in the iron-slag corrosion experiment. In fact, the ceramic cup generally has bad wettability with liquid iron (contact angle is more than 90 degree), whereas it has good wettability with liquid slag (contact angle is less than 90 degree) [26]. The composition of ceramic cup is generally oxides, which is more similar with that of liquid slag than liquid iron. Therefore, the slag corrosion is more severe than iron corrosion. The slag-iron corrosion of ceramic cup can be divided into two aspects: one is the reaction and dissolution with liquid iron and slag, as shown in Figure 9. The other is permeation of liquid iron and slag, as shown in Figure 10. Both of them lead to the destruction of ceramic cup.

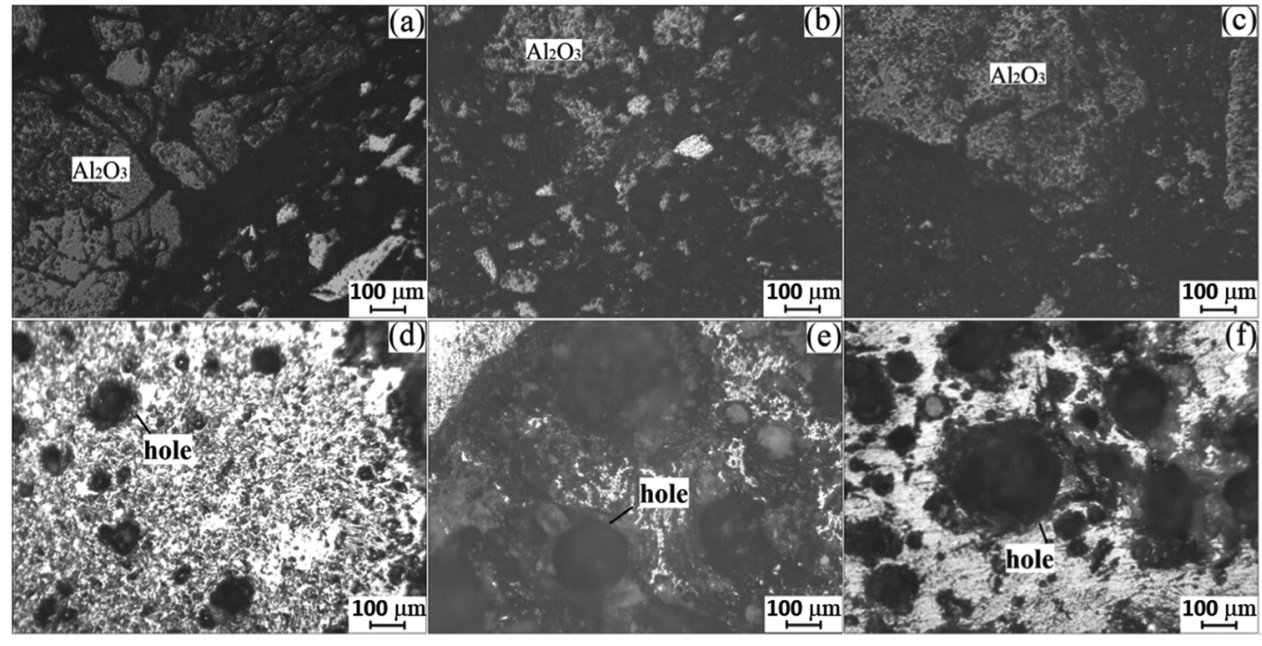

Figure 9: OM images of (a) original No. 1 sample, (b) original No. 2 sample, (c) original No. 3 sample, (d) No. 1 sample after corrosion, (e) No. 2 sample after corrosion and (f) No. 3 sample after corrosion. 


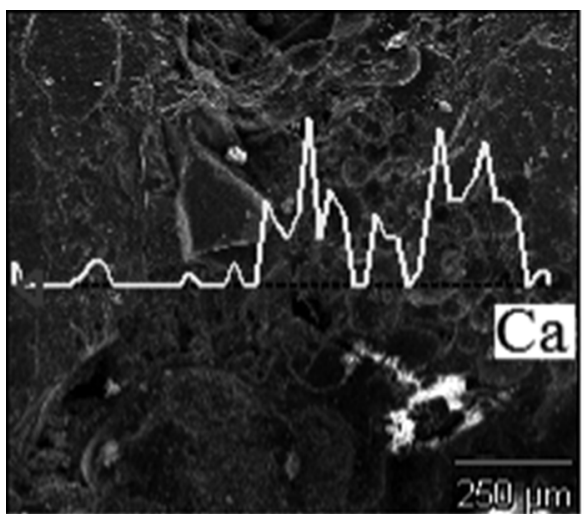

(a)

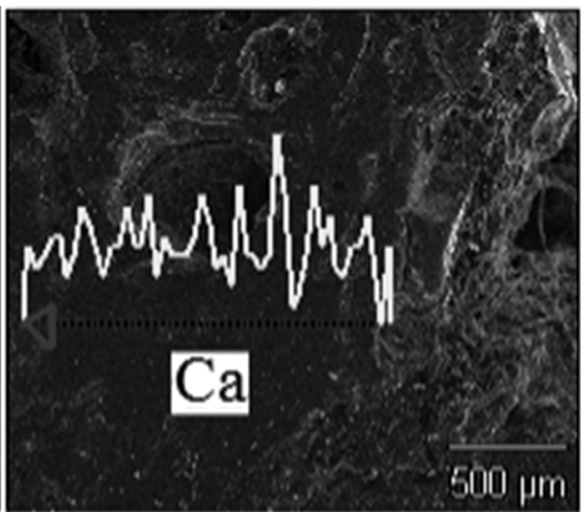

(b)
Figure 10: SEM images and line scanning of (a) No. 1 sample and (b) No. 2 sample after iron-slag corrosion experiment.
In iron-slag corrosion experiment, the most serious corrosion occurred in the iron-slag corrosion region. This is due to Marangoni effect [27], which is induced by the concentration gradient of $\mathrm{Al}_{2} \mathrm{O}_{3}$ and $\mathrm{SiO}_{2}$ in the film at the interface between liquid iron and slag film in the vertical direction. Mukai et al. [28] found the mechanism for the local corrosion of immersion nozzles at the slagmetal interface. The authors believe that the local corrosion of ceramic cup at the iron-slag interface is similar. Figure 11 shows the schematic diagram of the local corrosion at the iron-slag interface. Initially, the liquid iron wets and dissolves carbide in preference to the oxides, as shown in Figure 11(a). The sample surface near iron-slag interface turns to an oxide-rich layer. Due to the Marangoni effect, a slag film formed by the penetration between liquid iron and ceramic cup moves actively. Therefore, the sample surface near iron-slag interface can be covered with the slag film, as shown in Figure 11 (b). It will wet and dissolve the oxides in preference to carbide. This produces a carbide-rich layer. Since the liquid iron wets and dissolves carbide preferentially, the carbide-rich layer disappears gradually. Then the oxiderich layer can be formed again, as shown in Figure 11(c). The slag corrosion can reoccur when the slag film forms. This process repeats and produces a local corrosion at the iron-slag interface finally.
In these dynamic experiments, the influence of sample rotational speed is unexpected due to the change of slag composition. The molten slag reacted with ceramic cup and the content of $\mathrm{Al}_{2} \mathrm{O}_{3}$ in slag increased obviously after the experiment. It led to increasing activity of $\mathrm{Al}_{2} \mathrm{O}_{3}$ and decreasing chemical corrosion rate and dissolution rate. Therefore, the composition of slag has important influence on hearth lining erosion especially ceramic cup. The ceramic cup composition should be close to slag composition to decrease the chemical reaction, which needs a further research.

From the above experimental results, No. 1 sample has the best erosion resistance than other samples. It has low porosity, high SiC and good strength. Hence, improving the property of ceramic cup especially porosity and average pore size can slow down the erosion rate and prolong the life of ceramic cup. The temperature and slag composition have great influence on the erosion degree. In blast furnace hearth, there always exists liquid iron and slag with high temperature. The ceramic cup is inevitable to be eroded when it comes into contact with liquid iron and slag directly. However, if the skull forms on the hot surface of hearth lining, it will prevent the corrosion and decrease the lining temperature. Hence, it's very important to form stable skull to protect the hearth lining by reasonable design.
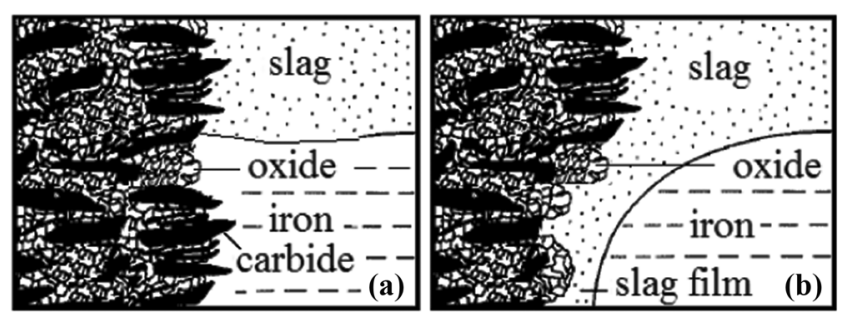

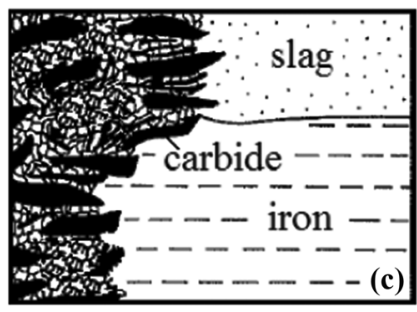

Figure 11: Schematic diagram of the local corrosion at the ironslag interface. 


\section{Conclusions}

In order to investigate the corrosion behavior of ceramic cup by flow liquid iron and slag, several corrosion experiments were conducted with different corrosion systems. Mass measurements and direct observations by $\mathrm{OM}$ and SEM were carried out. The following results are presented.

(1) The maximum mass loss of the samples appeared in iron-slag corrosion experiment. The mass loss percentage of No. 1-3 sample bricks was $2.6 \%, 4.7 \%$ and $3.5 \%$, respectively. The most serious corrosion occurred in the iron-slag corrosion region. Due to the Marangoni effect, slag film formed by the penetration between liquid iron and ceramic cup moves actively and results in local corrosion of ceramic cup at the iron-slag interface.

(2) The erosion degree of ceramic cup increased with increasing the temperature of liquid iron and slag from $1,623 \mathrm{~K}$ to $1,823 \mathrm{~K}$. A higher temperature of liquid iron and slag led to more serious corrosion. Therefore, decreasing the temperature of hearth lining is beneficial to prevent the corrosion of ceramic cup.

(3) The slag composition and activity of $\mathrm{Al}_{2} \mathrm{O}_{3}$ influence the corrosion degree of ceramic cup. With corrosion going on, the slag composition changed and the activity of $\mathrm{Al}_{2} \mathrm{O}_{3}$ increased. It led to the decrease of corrosion degree although the sample rotational speed was increased in this experiment. The ceramic cup composition should be close to slag composition to decrease the chemical reaction. It needs further research.

(4) For the sake of prolonging the life of ceramic cup in blast furnace hearth, the ceramic cup should have good performance especially slag resistance. A microporous and strong ceramic cup can improve the corrosion resistance, such as No. 1 sample. The skull formed on the hot surface of hearth lining can prevent the corrosion and decrease the lining temperature. Therefore, it's also very important to form skull to protect the hearth lining by reasonable hearth design.

Acknowledgments: The authors would like to thank the personnel at Gongyi Tongda Zhongyuan Refractory Technology Co. Ltd., especially the technicians of hightemperature laboratory for help with experiment work.
Funding: The authors are grateful for financial support from the National Natural Science Foundation of China (No. 61271303).

\section{References}

[1] F.M. Zhang, J. Iron Steel Res. Int., 20 (2013) 53-60.

[2] R.M. Duarte, I. Ruiz-bustinza, D. Carrascal, L.F. Verdeja, J. Mochon and A. Cores, Ironmaking Steelmaking, 40 (2013) 350-359.

[3] H.B. Zhao and S.S. Cheng, J. Univ. Sci. Technol. Beijing, 13 (2006) 497-503.

[4] H.B. Zhao, S.S. Cheng and M.G. Zhao, J. Iron Steel Res. Int., 14 (2007) 6-12.

[5] Y.G. Cao, R.T. Xu, R.S. He, S.L. Wu and H.L. Han, Rev. Métall., 108 (2011) 277-282.

[6] H.B. Zhao, S.F. Huo and S.S. Cheng, Int. J. Miner. Metall. Mater., 20 (2013) 345-353.

[7] M. Zagaria, V. Dimastromatteo and V. Colla, Ironmaking Steelmaking, 37 (2010) 229-234.

[8] S. Kumar, ISIJ Int., 45 (2005) 1122-1128.

[9] J. Brannbacka, J. Torrkulla and H. Saxen, Ironmaking Steelmaking, 32 (2005) 479-486.

[10] B.Y. Guo, D. Maldonado, P. Zulli and A.B. Yu, ISIJ Int., 48 (2008) 1676-1685.

[11] C.E. Huang, S.W. Du and W.T. Cheng, ISIJ Int., 48 (2008) 1182-1187.

[12] M.F. Barbes-fernandez, E. Marinas-garcia, E. Brandaleze, R. Parra-figueroa, L.F. Verdeja-gonzalez, G.A. Castillorodrigurez and R. Colas, ISIJ Int., 48 (2008) 134-140.

[13] V. Panjkovic, J.S. Truelove and P. Zulli, Ironmaking Steelmaking, 29 (2002) 390-400.

[14] S.K. Dash, D.N. Jha, S.K. Ajmani and A. Upadhyaya, Ironmaking Steelmaking, 31 (2004) 207-215.

[15] M. Swartling, B. Sundelin, A. Tilliander and P. Jonsson, Ironmaking Steelmaking, 37 (2010) 21-26.

[16] T. Inada, A. Kasai, K. Nakano, S. Komatsu and A. Ogawa, ISIJ Int., 49 (2009) 470-478.

[17] A. Shinotake, H. Nakamura, N. Yadoumaru, Y. Morizane and M. Meguro, ISIJ Int., 43 (2003) 321-330.

[18] S.N. Silva, F. Vernilli, S.M. Justus, O.R. Marques, A. Mazine, J.B. Baldo, E. Longo and J.A. Varela Ironmaking Steelmaking, 32 (2005) 459-467.

[19] L.A. Diaz, R. Torrecillas, A.H. de Aza and P. Pena J. Eur. Ceram. Soc., 27 (2007) 4623-4631.

[20] M.K. Cho, G.G. Hong and S.K. Lee, J. Eur. Ceram. Soc., 22 (2002) 1783-1790.

[21] K. Mukai, J.M. Toguri and J. Yoshitomi, Can. Metall. Q., 25 (1986) 265-275.

[22] M.A.L. Braulio, A.G. Tomba Martinez, A.P. Luz, C. Liebske and V.C. Pandolfelli, Ceram. Int., 37 (2011) 1935-1945.

[23] H. Saxen and J. Brannbacka, Scand. J. Metall., 34 (2005) 116-121.

[24] Z.Y. Chen, J. Chin. Ceram. Soc., 11 (1983) 498-506.

[25] W.Q. Chen and L.R. Dong, Iron and Steel, 17 (1982) 7-15.

[26] K. Nakashima and K. Mori, ISIJ Int., 32 (1992) 11-18.

[27] K. Mukai, ISIJ Int., 32 (1992) 19-25.

[28] K. Mukai, J.M. Toguri, N.M. Stubina and J. Yoshitomi, ISIJ Int., 29 (1989) 469-476. 